\title{
Cyclical behaviour of the tide-pool ciliate Strombidium oculatum
}

\author{
David J. S. Montagnes ${ }^{1, *}$, David Wilson ${ }^{2}$, Steven J. Brooks ${ }^{3}$, Chris Lowe ${ }^{2}$, \\ Michael Campey ${ }^{1}$
}

\author{
${ }^{1}$ Port Erin Marine Laboratory, School of Biological Sciences, University of Liverpool, Port Erin, Isle of Man IM9 6JA, \\ British Isles \\ ${ }^{2}$ School of Biological Sciences, University of Liverpool, Liverpool L69 7ZB, United Kingdom \\ ${ }^{3}$ Nottingham Trent University, Department of Life Sciences, Erasmus Darwin Building, Clifton Lane, Clifton, \\ Nottingham NG11 8NS, United Kingdom
}

\begin{abstract}
This study developed a field-based system to examine the influence of cyclical disturbances on populations and metapopulations. We have examined the population dynamics of a tidepool ciliate that possesses several cycles, endogenously and exogenously induced, ranging in scale from hours to years. Strombidium oculatum Gruber exhibits an endogenous circatidal behaviour: for $\sim 6 \mathrm{~h}$, at low tide, $S$. oculatum is free-swimming in pools, and $\sim 20$ to 60 min before flushing of the pools it encysts on a substrate. Encystment lasts for $\sim 19$ h: 2 high tides and 1 intervening low tide. Excystment then occurs the next day $\sim 30$ to $40 \mathrm{~min}$ after the pools are isolated. This behaviour allows $S$. oculatum to remain in pools and creates isolated populations; a matrix of such pools on the shore then comprises a metapopulation. Over a 5 yr period, we conducted a study to examine (1) the timing of division and the cell cycle; (2) the endogenous, $25 \mathrm{~h}$ encystment-excystment cycle; (3) the tidally induced fortnightly behaviour; (4) the seasonally induced long-term variation in population abundance; and (5) the seasonal change in distribution on the shore. We found that ciliates on the Isle of Man exhibit an excystment-encystment pattern similar to that previously described for populations of $S$. oculatum in France: cells divide almost immediately after excysting, allowing the ciliate population to rapidly exploit potential food resources; 2 populations exist in each pool, each isolated to a single low tide; the ciliate exhibits seasonal trends in population dynamics, appearing in the spring and disappearing in the autumn; and ciliates appear to survive seasonal changes by remaining at low densities in upper-shore pools during the winter. We have used these data and other measurements of the population dynamics to discern how populations are maintained on the shore, and we discuss these mechanisms in the context of population-metapopulation survival.
\end{abstract}

KEY WORDS: Ciliate $\cdot$ Circadian rhythm $\cdot$ Circatidal behaviour $\cdot$ Metapopulation $\cdot$ Oligotrich

\section{INTRODUCTION}

This study developed a field-based system to examine the influence of cyclical disturbances on populations and metapopulations; a metapopulation being a local set of, potentially ephemeral, populations, connected by migrations (e.g. Hanski \& Gilpin 1997,

*E-mail: dmontag@liv.ac.uk
Holyoak 2000). Populations are often governed by cyclic behaviours, and such behaviours may occur in response to environmental factors, on a variety of scales. These cycles, in turn, may be maintained endogenously by circadian clocks or by exogenous environmental cues (Cloudsley-Thompson 1961, Palmer 1995). We have examined the population dynamics of a tide-pool ciliate that exhibits several cycles, endogenously and exogenously induced, ranging in scale from hours to years. 
The intertidal fauna in general and specifically tidepool fauna can act as model systems for population studies (Raffaelli \& Hawkins 1996, Johnson 2000). For intertidal organisms, the tidal cycle constitutes a major environmental disturbance, and tidal effects are especially pronounced for protozoa, which are often abundant in tide pools (Scherren 1900, Fauré-Fremiet 1953). Furthermore, as protozoan generation times are on the order of hours to days, they are useful model organisms to investigate population dynamics, the effects of disturbance and cyclical behaviours (e.g. Gause 1934, Holyoak 2000). By recognising the behaviour and distribution of these organisms, we can provide key information about survival strategies of tide-pool fauna and offer insight into general phenomena concerning the dynamics of populations and metapopulations. This study, thus, focused on how 1 protozoan survives in tide pools; in doing so we indicate the occurrence of both general and unique adaptations to a high-disturbance environment.

The ciliate Strombidium oculatum Gruber, 1884 (Fig. 1) was described from shallow waters of Genoa harbour, Italy. Later, it was observed in tide pools in Brittany, France (Fauré-Fremiet 1948a,b, 1953, Jonsson 1994) and more recently on the Isle of Man; for a taxonomic review of $S$. oculatum see Montagnes et al. (2002). Fauré-Fremiet (1948a), Jonsson (1994), and Montagnes \& Wilson (1998) have indicated that S. oculatum exhibits an endogenous circatidal behaviour: for $\sim 6 \mathrm{~h}$, at low tide, $S$. oculatum is free-swimming in pools, and $\sim 20$ to 60 min before flushing of the pools it encysts on a substrate. Encystment lasts for $\sim 19$ h (incorrectly considered to be $18 \mathrm{~h}$ in previous studies; e.g. FauréFremiet 1948a): 2 high tides and 1 intervening low tide. Excystment then occurs the next day $\sim 30$ to 40 min after the pools are isolated. This behaviour allows $S$. oculatum to remain in pools and creates isolated populations.

Although Strombidium oculatum has not been grown in culture, both Fauré-Fremiet (1948a) and Jonsson (1994) have maintained populations for several days; using laboratory-based experiments, these authors examined the ciliate's behaviour. In contrast, we have conducted field studies, focusing on spatial and temporal cyclical behaviours and distributions. We have also complemented these previous studies with further laboratory investigations that examined fine details of the circatidal behaviour and re-examined the timing of the cycle. We then developed several general hypotheses concerning the survival of populations and metapopulations on a range of spatial and temporal scales. Ultimately, we suggest that data from this and other studies provide useful parameters for models of metapopulation dynamics. Such field-based systems are needed to explore hypotheses arising from computer models and laboratory-based studied (e.g. Jonsson 1994, Holyoak 2000, Johnson 2000).

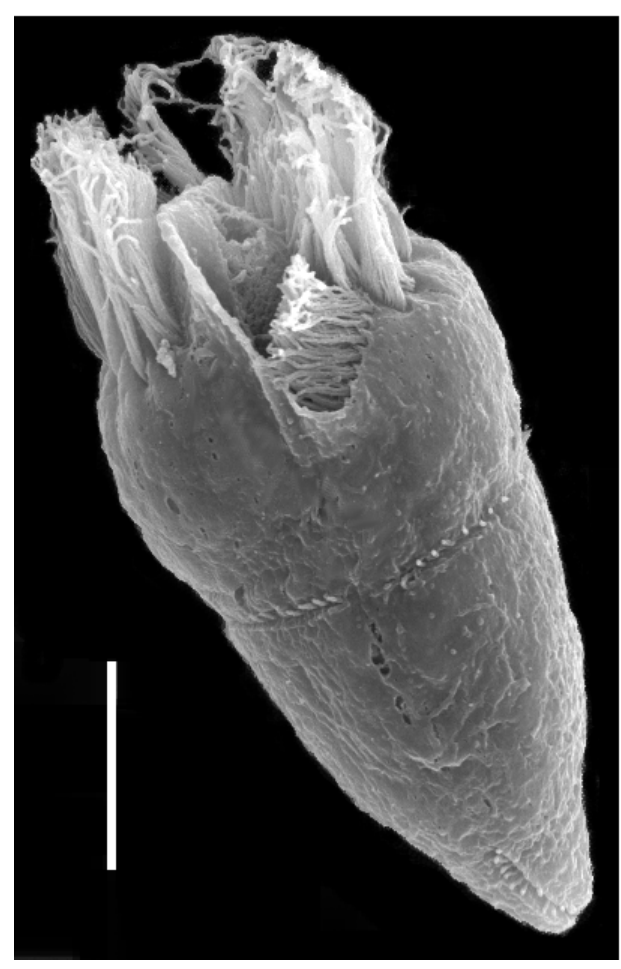

Fig. 1. Strombidium oculatum. Scanning electron micrograph (SEM) of the free-swimming phase. Scale bar $=10 \mu \mathrm{m}$

\section{MATERIALS AND METHODS}

Population dynamics during low tide. Sampling was conducted on 28 June 1999 at Site L (Fig. 2). Two pools were sampled, one at $5.6 \mathrm{~m}$ above lowest astronomical tide (LAT) and one at $4.8 \mathrm{~m}$ above LAT. Samples were collected from pools at 15 min intervals from the point of tidal isolation until pools were flooded by the incoming tide $(\sim 7 \mathrm{~h})$, using the following method: a piece of rigid polyvinyl chloride (PVC) tubing $(30 \mathrm{~cm}$ length, $3.8 \mathrm{~cm}$ diameter) was lowered vertically into the water, and a rubber bung was placed into the top, forming a seal. The tube was then partially raised and a second bung pressed into the bottom of the tube, taking a core of water. This method removed the sampling bias potentially caused by vertical heterogeneity of ciliate distribution (Jonsson 1994). The tube was then gently inverted to mix the water. All samples in this study were collected using this technique, unless otherwise stated. At each sampling time, 3 independent samples were taken using the tube method above; $20 \mathrm{ml}$ from each sample was fixed in Lugol's iodine (2\% final concentration, Throndsen 1978) to estimate ciliate abundance (2\% Lugol's samples provide data $90 \%$ of live-linear dimensions and $77 \%$ of live-volume measurements; Montagnes et al. 2002). Two further samples $(20 \mathrm{ml})$ were fixed in glutaraldehyde $(1 \%$ final 


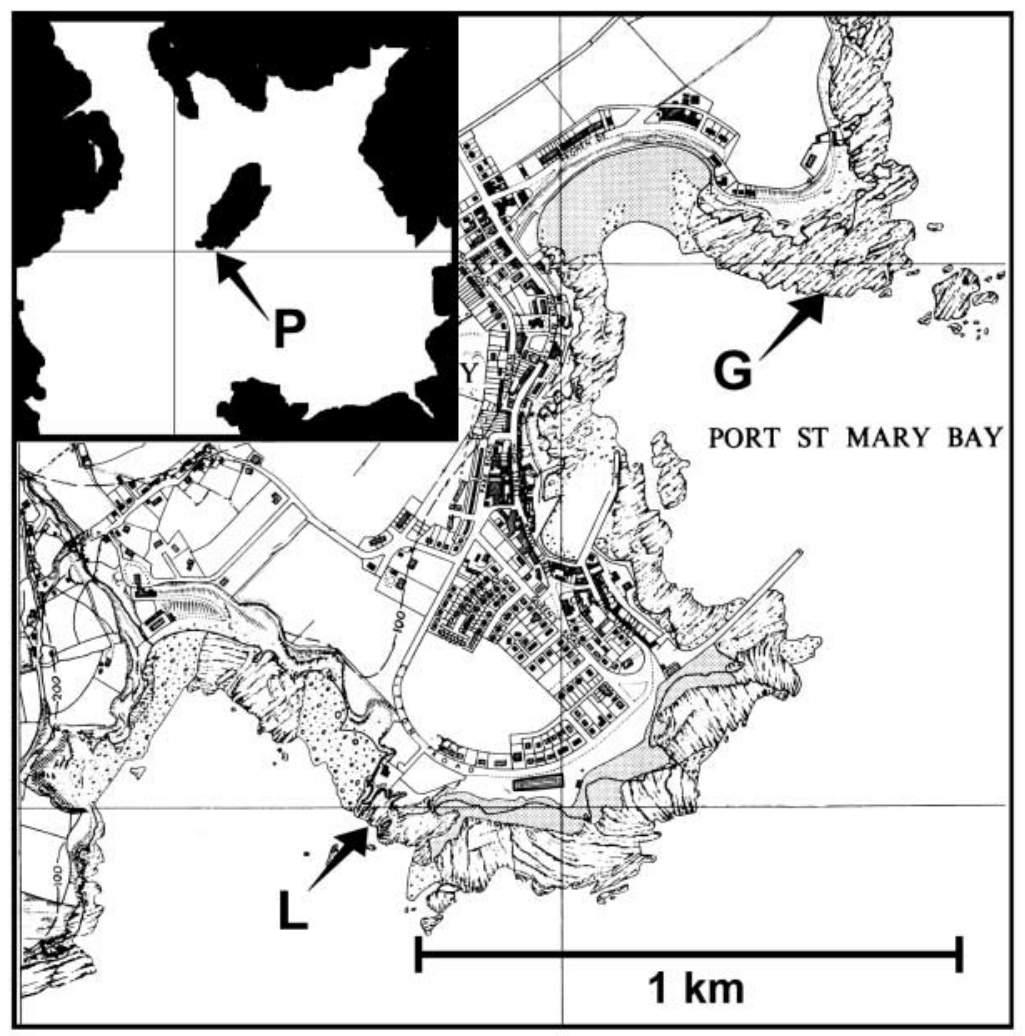

Fig. 2. Location of the 2 sampling locations used in this study: Port St Mary Ledges (L) and Gansey Point (G) on the Isle of Man. The inset of the Irish Sea shows the location of Port St Mary (P) on the Isle of Man

abundance, salinity and temperature. Samples were taken over $36 \mathrm{~h}$ to include 3 high and 3 low tides. This procedure was repeated on 21 July 1997 at a second site (Site L, Fig. 2) at 2 other similar-sized pools located at 5.6 and $5.2 \mathrm{~m}$ above LAT. Samples were collected as described above, and $100 \mathrm{ml}$ was preserved with $2 \%$ Lugol's iodine at each sampling time. The $100 \mathrm{ml}$ was concentrated to $10 \mathrm{ml}$ by settling, or if abundance was high, a $10 \mathrm{ml}$ sub-sample was analysed directly for ciliate abundance.

Fortnightly variation in ciliate abundance. Knowing that low tides proceed relative to the solar day, we examined the fluctuation in population abundance during half a lunar cycle. Between 28 October 1997 and 12 November 1997, 3 replicate pools (Site L, Fig. 2) (0.5 to $1.0 \mathrm{~m}$ diameter, 0.2 to $0.3 \mathrm{~m}$ depth) were sampled $2 \mathrm{~h}$ prior to each low tide for $2 \mathrm{wk}$. Sampling and Lugol's preservation followed methods described above. For presentation purposes (see 'Results'), the population initially sampled during the day (low tide 15:22 h) is named Population I, and the population initially sampled during the night is Population II (low

concentration) for observations of nuclear morphology. Abundance was determined by the Utermöhl method (Hasle 1978).

Nuclei were observed and measured after staining with 4',6-diamidino-2-phenylindole (DAPI) (Sherr et al. 1993). Nuclei were observed and measured using an inverted microscope (Zeiss Axiovert) equipped with a fluorescent light source (UV mercury lamp illumination, 340 to $380 \mathrm{~nm}$ excitation, 450 to $490 \mathrm{~nm}$ barrier filter) and a video camera (JVC model KY-F55B, 3CCD, 750 horizontal $\times 480$ vertical line resolution) attached to a Pentium II PC with image analysis software (Scion image for Windows, Scion). Dividing nuclei were recognisable as pinched, bilobed or fully separated into daughter nuclei. Nuclei undergoing DNA synthesis were recognisable as bearing a replication band (Raikov 1996). To assess timing of division, the percentage of cells undergoing division and nuclear replication were calculated; 20 to 100 cells were examined at each time period.

Daily variation in ciliate abundance. On 12 August 1996, 3 replicate pools on a rocky shore (Site G, Fig. 2), $\sim 1$ to $3 \mathrm{~m}$ diameter, 0.2 to $0.3 \mathrm{~m}$ depth, $4 \mathrm{~m}$ height above LAT were sampled for Strombidium oculatum tide 03:04 h). Over 2 wk we examined day and night populations as they became night and day populations, respectively.

Long-term seasonal variation. To examine the annual change in ciliate abundance, a single pool ( 0.5 length, $0.25 \mathrm{~m}$ width, $0.25 \mathrm{~m}$ depth, $5.6 \mathrm{~m}$ height above LAT, Site L, Fig. 2) was sampled weekly or fortnightly, between 12 October 1997 and 14 August 2001. On each sampling occasion, 3 replicate samples were taken, as described above, and water temperature in the pool was measured. Efforts were made to always sample at the same time: $2 \mathrm{~h}$ after low tide.

Annual variation in daily integrated light intensity was also examined. In the absence of real-time measurements, a predictive annual light intensity curve was modelled using previously collected data. A 5 yr record of average daily light intensity $\left(\mathrm{mol} \mathrm{m}^{-2} \mathrm{~d}^{-1}\right)$ was collected between 1970 and 1974 at Port Erin Marine Laboratory IOM (courtesy of J. Jones). These unpublished data were used to model annual light intensity using a second-order quadratic function (non-linear curve fitting function, SPSS, Sigmaplot v5.0). Hours of daylight (sunrise to sunset) were also obtained from published tide tables. 
Seasonal variation in vertical distribution on the shore. Sampling was conducted at Site L (Fig. 2) on 28 January 1998, 15 March 1998, 25 May 1998, 2 August 1998 and 17 August 1998. Samples were collected, as described above, at 2.5, 3.6, 4.8, 5.6, 6.5 and $7.4 \mathrm{~m}$ above LAT, with 4 replicate pools per height and 3 samples per pool. On 25 May 1998, several pools at 6.5 and $7.4 \mathrm{~m}$ were dry; these pools were given a value of 0 ciliates $\mathrm{ml}^{-1}$. A nested ANOVA was applied to the data to test for differences in abundance between pools at a single height and between pools at different heights, independently for each sampling date; this test indicated no differences between heights as a result of high variation between pools at a single height (see 'Results').

A subset of the data was then used to assess whether there were any potential differences between heights; an assumption was made that the pool at each height with the highest abundance represented a potential maximum at that height. Then, a second ANOVA was conducted to examine whether abundance differed between heights, using only the pool with the highest ciliate abundance at each height. This test indicated differences and was followed by a Tukey multiple comparison test. All tests were run at $\alpha=0.05$. Data were log transformed to reduce heteroscedasticity.

Encystment-excystment study. Field data suggested that Strombidium oculatum might exhibit a 6:6 $\mathrm{h}$ cycle, rather than the expected $6: 19 \mathrm{~h}$ encystment-excystment cycle (see Results; Jonsson 1994). Free-swimming ciliates were impossible to count in laboratory experiments. Consequently, the appearance and disappearance of encysted ciliates, in tissue culture plates, was examined to determine this cycle.

The following experiment was devised. Nighttime water samples (6 l) were taken from 3 replicate pools at 18:20 h (19 October 1997, Site L, Fig. 2), $2 \mathrm{~h}$ before low tide (for presentation purposes these samples are labelled a-population). Then, a daytime set of samples (6 l) was taken from the same pools, during the consecutive low tide at 06:40 h (b-population).

To obtain a sufficient number of ciliates, freeswimming ciliates from night- and daytime sample

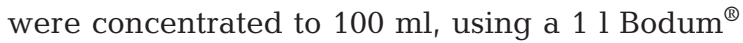
coffee plunger system, fitted with a $90 \mathrm{~mm}$ Whatman GF/F filter. Four $\mathrm{ml}$ of these concentrated samples was then placed in wells of plastic tissue culture plates ( $5 \mathrm{ml}$ well capacity); i.e. there were 6 wells, each containing free-swimming ciliates from 1 of the 3 pools for 1 sampling time.

Tissue plates were stored in sealed clear plastic bags under ambient temperature and light condi- tions. Ciliates began to encyst after being transferred to wells. To determine the abundance of cysts, each well was examined hourly, using an inverted microscope $(100 \times$ magnification). The appearance and disappearance of ciliates in cysts was then recorded over the equivalent of 4 low tides.

\section{RESULTS}

\section{Population dynamics during low tide}

Excysted ciliates were present, in both pools, for the entire period during which pools were isolated (Fig. 3). Abundance increased in both pools over the first 2.0 to $2.5 \mathrm{~h}$ after tidal isolation. After 2.0 to $2.5 \mathrm{~h}$ there was a consistent decrease in abundance. At the point when pools were covered by the incoming tide, $\sim 6 \%$ of the maximum population had not encysted (Fig. 3a,d).

In both populations, nuclei underwent division prior to and concurrent with the increase in ciliate abundance; this occurred during the first $2 \mathrm{~h}$ of low tide (Fig. 3b,e). Note that ciliates excysted during this time; i.e. increase in number of free-swimming
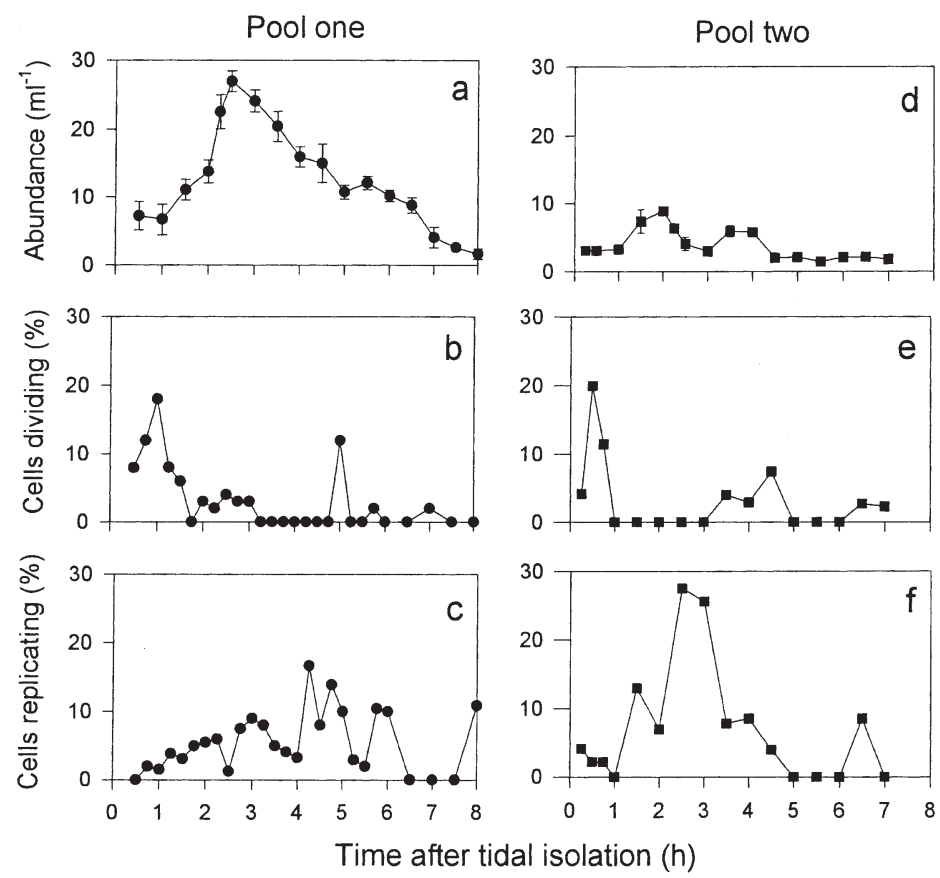

Fig. 3. Strombidium oculatum. (a,d) Abundance; (b,e) percentage frequency of dividing cells; $(\mathrm{c}, \mathrm{f})$ percentage frequency of cells undergoing macronuclear replication in 2 pools during a single low-tide period. Pool 1 (a to c) was $0.8 \mathrm{~m}$ higher on the shore than pool 2 ( $\mathrm{d}$ to $\mathrm{f}$ ); thus, the period of tide exposure was longer in pool 1. Data points represent the mean of 3 samples $(a, d)$ or 20 to 100 cells $(\mathrm{b}, \mathrm{c}, \mathrm{e}, \mathrm{f})$; error bars $=1 \mathrm{SE}$ 
Fig. 4. Field observations of the change in abundance of Strombidium oculatum over the day-night cycle. (a) Change in abundance of $S$. oculatum (bottom panel), temperature (middle panel) and salinity (top panel) in 3 replicate tide pools $(\bullet, \bullet, \mathbf{\bullet})$ at Site G (Fig. 2) over $\sim 3$ low and $\sim 3$ high tides. The solid line (bottom panel) is the mean abundance of ciliates in the 3 pools. Vertical lines represent when pools were isolated by the outgoing tide (I) and covered by the incoming tide (C). Days and nights were delineated by sunrise and sunset. (b) Abundance of $S$. oculatum in 2 replicate pools (• and $\square$ ) at Site L (Fig. 2) over 2 low and $\sim 2$ high tides; vertical bars are as described above
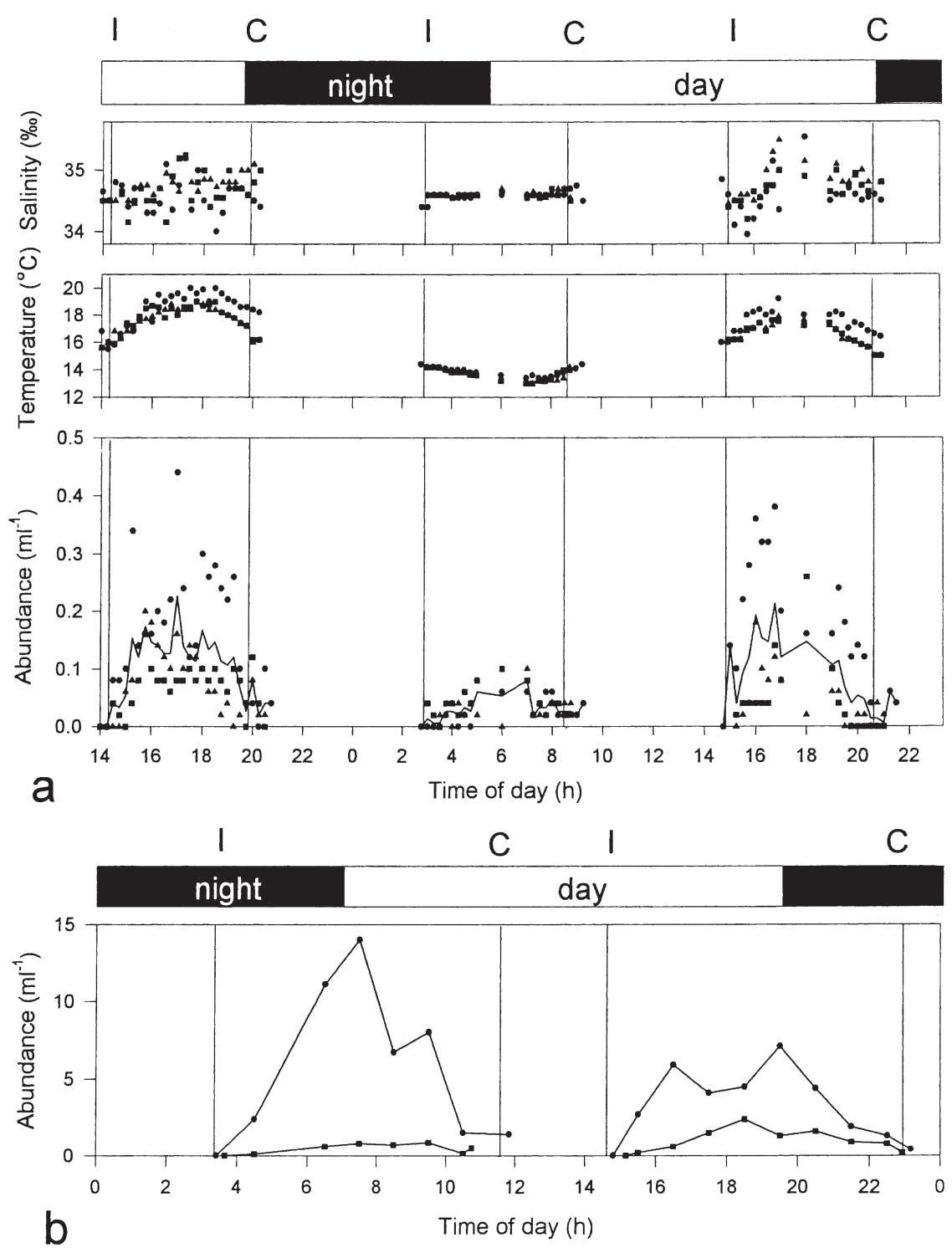

cells is not exclusively due to cell division. Between 0.25 and $6 \mathrm{~h}$, nuclei undergoing DNA replication were consistently observed. The highest frequency of nuclei undergoing DNA replication occurred at $2.5 \mathrm{~h}$ and $4.0 \mathrm{~h}$ after tidal isolation in pools 1 and 2 , respectively (Fig. 3c,f). This timing of cell cycle events indicates that ciliates excyst after having replicated their macronuclear DNA in the previous free-swimming period; i.e. after excystment, cells divide, and this is followed by replication of macronuclear DNA. This order of division and DNA replication, relative to the point of excystment, indicates that cells maintain a nucleus containing replicated DNA during the latter half of the low-tide (freeswimming) phase and throughout the entire encysted phase.

\section{Daily variation in ciliate abundance}

Free-swimming ciliates existed in tide pools during consecutive low tides. However, nighttime low-tide populations were smaller than daytime populations; this trend was consistent for most pools studied (Figs. $4 \mathrm{a} \& 5$ ). Salinity in the pools was stable during the night and varied during the day, tending to increase during the day by $\leq 1 \%$. Temperature in the pools rose $\left(\sim 5^{\circ} \mathrm{C}\right)$ during the day and fell $\left(\sim 2^{\circ} \mathrm{C}\right)$ during the night (Fig. 4a).

The pattern of ciliate abundance during low tide was similar to that described above (Fig. 3a,d). Ciliate abundance increased immediately after pools were isolated by the receding tide, increased over a 3 to $4 \mathrm{~h}$ period, and then decreased before the pools were cov- 


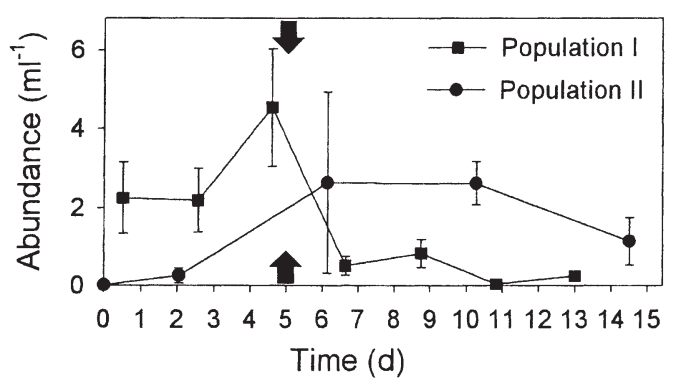

Fig. 5. Strombidium oculatum. Change in abundance in 3 replicate pools (Site L, Fig. 2) sampled every second day. Time, in days, starts at the initial sampling; sampling occurred $2 \mathrm{~h}$ before low tide. Both low tides each day were sampled on each occasion; samples taken initially during the day are Population I; samples initially taken at night are Population II. As the tidal cycle is on a $\sim 25 \mathrm{~h}$ clock and days are $24 \mathrm{~h}$, the daytime low tide became the nighttime low tide and vice versa during the span of this experiment. At the time of this experiment there were $\sim 12$ daylight hours. Arrows represent when low tides occurred at dawn or dusk. Data points are the mean abundance in the 3 pools; error bars $=1 \mathrm{SE}$

ered by the incoming tide. Between 10 and $35 \%$ of the ciliates were still free-swimming when pools were covered by the flood tide (Fig. 4).

\section{Fortnightly variation in ciliate abundance}

Over a fortnight we examined the abundance of dayand nighttime populations as they became night- and daytime populations, respectively. At the start of the period, Population I (initially the daytime low-tide population) was larger than Population II (initially the nighttime low-tide population) (Fig. 5). This trend was reversed halfway through the 2 wk period, coinciding with the time when low tides occurred at dawn and dusk (arrow, Fig. 5).

\section{Long-term seasonal variation}

A seasonal trend in abundance was exhibited by Strombidium oculatum. Ciliate abundance rapidly increased in the spring and reached a maximum abundance of $>10$ cells $\mathrm{ml}^{-1}$ in the summer, which then decreased to $<0.1$ cells $\mathrm{ml}^{-1}$ in the late autumn and winter; this seasonal trend was repeated during each of the $4 \mathrm{yr}$ (Fig. 6). Abundance and the timing of the growth period varied between years. However, the timing of population increase was consistent between years; ciliates tended to increase in numbers

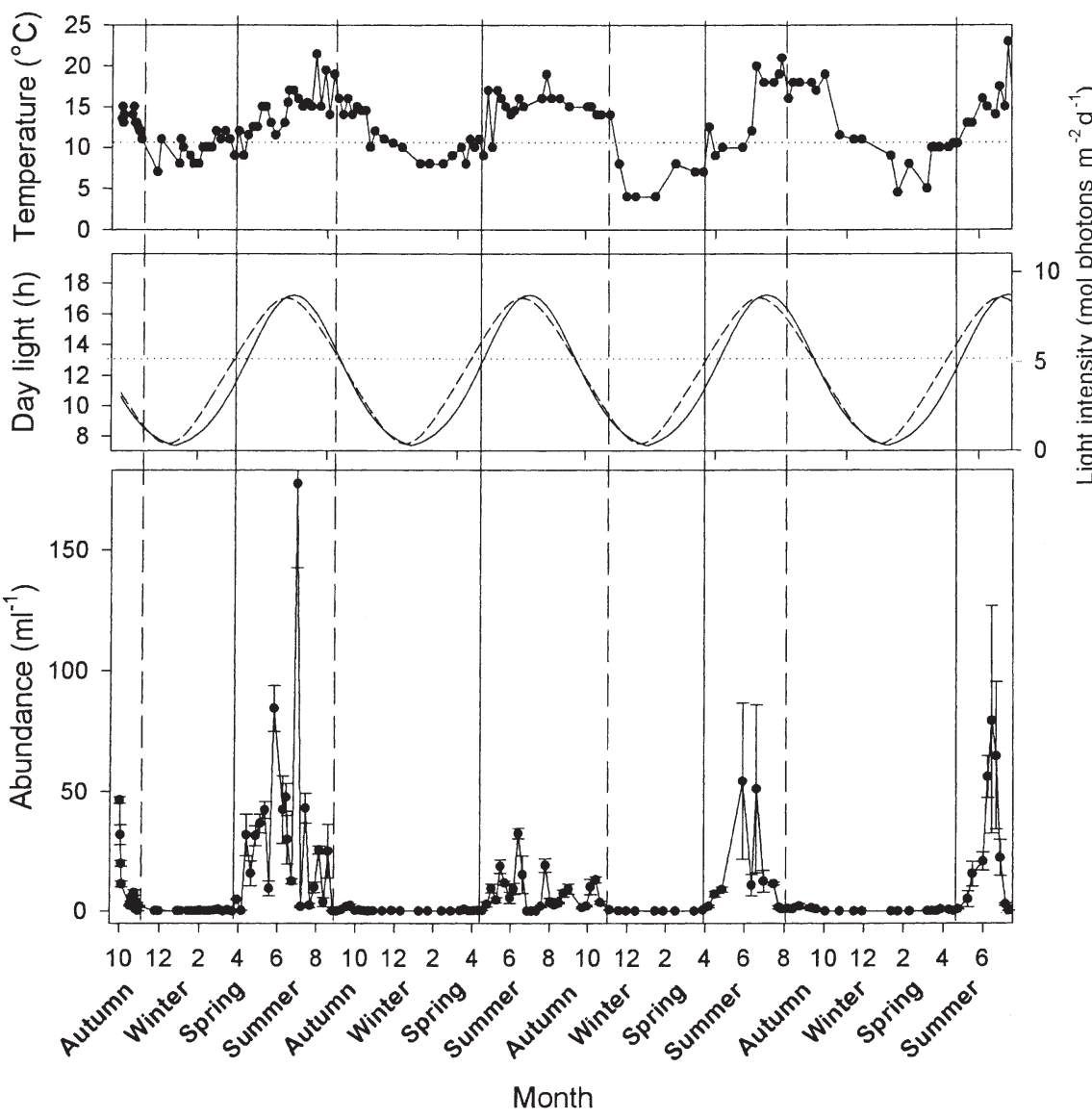

Fig. 6. Change in ciliate abundance, light levels and temperature over $\sim 4 \mathrm{yr}$, measured for 1 pool in the mid-shore (Site L, Fig. 2). Bottom panel: Strombidium oculatum abundance. Data points are the mean of 3 samples; error bars = 1 SE. Middle panel: average light intensity (solid line, mol photons $\mathrm{m}^{-2} \mathrm{~d}^{-1}$ ) modelled from a $5 \mathrm{yr}$ data set (see Fig. 7 and 'Results') and total hours of daylight (dashed line), measured as the period between sunrise and sunset. Top panel: temperature $\left({ }^{\circ} \mathrm{C}\right)$, recorded at each point where ciliate samples were taken. Vertical lines indicate when the population began to increase in the spring; dashed lines represent when it decreased in the autumn. Dotted lines represent the light and temperature levels that correspond to the spring increase in ciliate abundance 


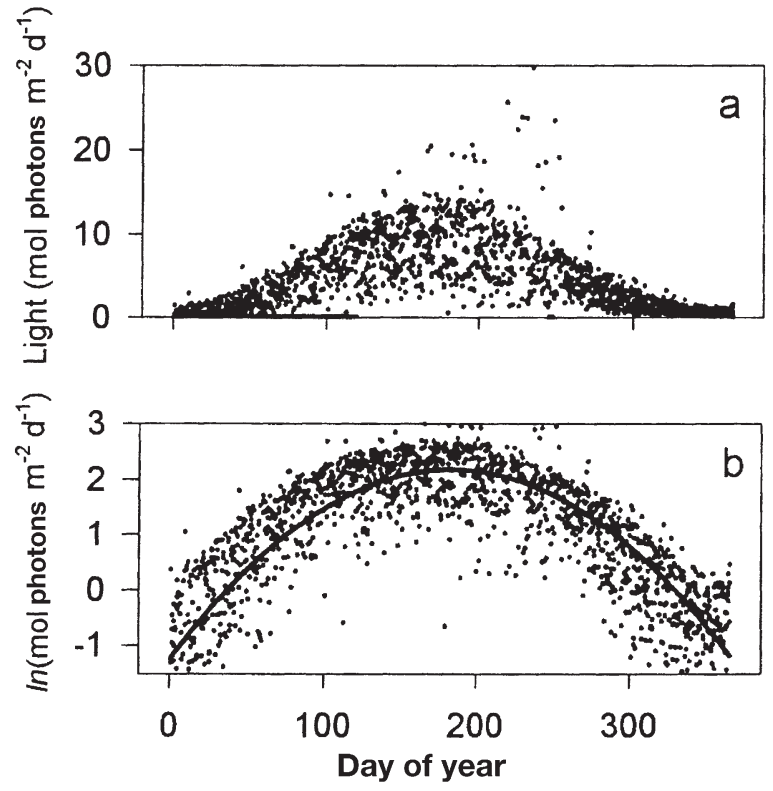

Fig. 7. Daily change in light levels (mol photons $\mathrm{m}^{-2} \mathrm{~d}^{-1}$ ) at Port Erin Marine Laboratory, Isle of Man $\left(54^{\circ} 05^{\prime} \mathrm{N}, 4^{\circ} 45^{\prime} \mathrm{W}\right)$ over 5 yr (1970 to 1974); data points represent the integrated value over $1 \mathrm{~d}$. (a) Raw data; (b) natural log of data; the solid line is the best fit through the data (see 'Materials and methods'); the equation of this line is $\ln L=-1.26+3.74 \times 10^{-2} \mathrm{~d}$ $-1.018 \times 10^{-4} \mathrm{~d}^{2}$, where $L$ is light (mol photons $\mathrm{m}^{-2} \mathrm{~d}^{-1}$ ) and $\mathrm{d}$ is 1 Day of year $(0=$ January 1$)$ in April of each year (solid vertical lines, Fig. 6). Modelled light intensity data are presented in Fig. 7; output from this model and the number of daylight hours are presented in Fig. 6. The annual increase in ciliates corresponded to changes in light levels and temperature; the population increased at a point where light levels were above $\sim 13 \mathrm{~h}$ light $\mathrm{d}^{-1}$ or 5 to $6 \mathrm{~mol} \mathrm{~m}^{-2} \mathrm{~d}^{-1}$ and temperature rose above $10^{\circ} \mathrm{C}$. There was no clear relationship between the autumnal decrease in ciliates and light or temperature levels (dashed vertical lines, Fig. 6). There were also no clear trends in ciliate abundance related to the minor fluctuations in salinity (data not shown). Multiple and single regressions incorporating salinity, temperature and light levels did not provide a means to predict ciliate numbers (unpubl. analysis).

\section{Seasonal variation in vertical distribution}

There were no significant differences $(\alpha=0.05)$ in ciliate abundance between heights for any date when all 4 pools at all heights were examined (Fig. 8a to e); i.e. variation in abundance between pools at a single height was as great as the variation between pools at
Fig. 8. Strombidium oculatum. Vertical distribution on the shore at Site L (Fig. 2) on 4 sampling occasions (28 January, 15 March, 25 May, 2 August, 17 August). (a to e) Vertical distribution of $S$. oculatum at 6 heights, with replicate pools at each height $(\mathrm{n}=4)$; data points are the mean abundances of 4 pools at each height; error bars $=1 \mathrm{SE}$. (f to k) Vertical distribution of $S$. oculatum at 6 heights, only examining the pool at each height containing the highest abundance of ciliates; data points are the mean abundance of 3 replicate samples from each pool; error bars = 1 SE. LAT: Lowest astronomical tide

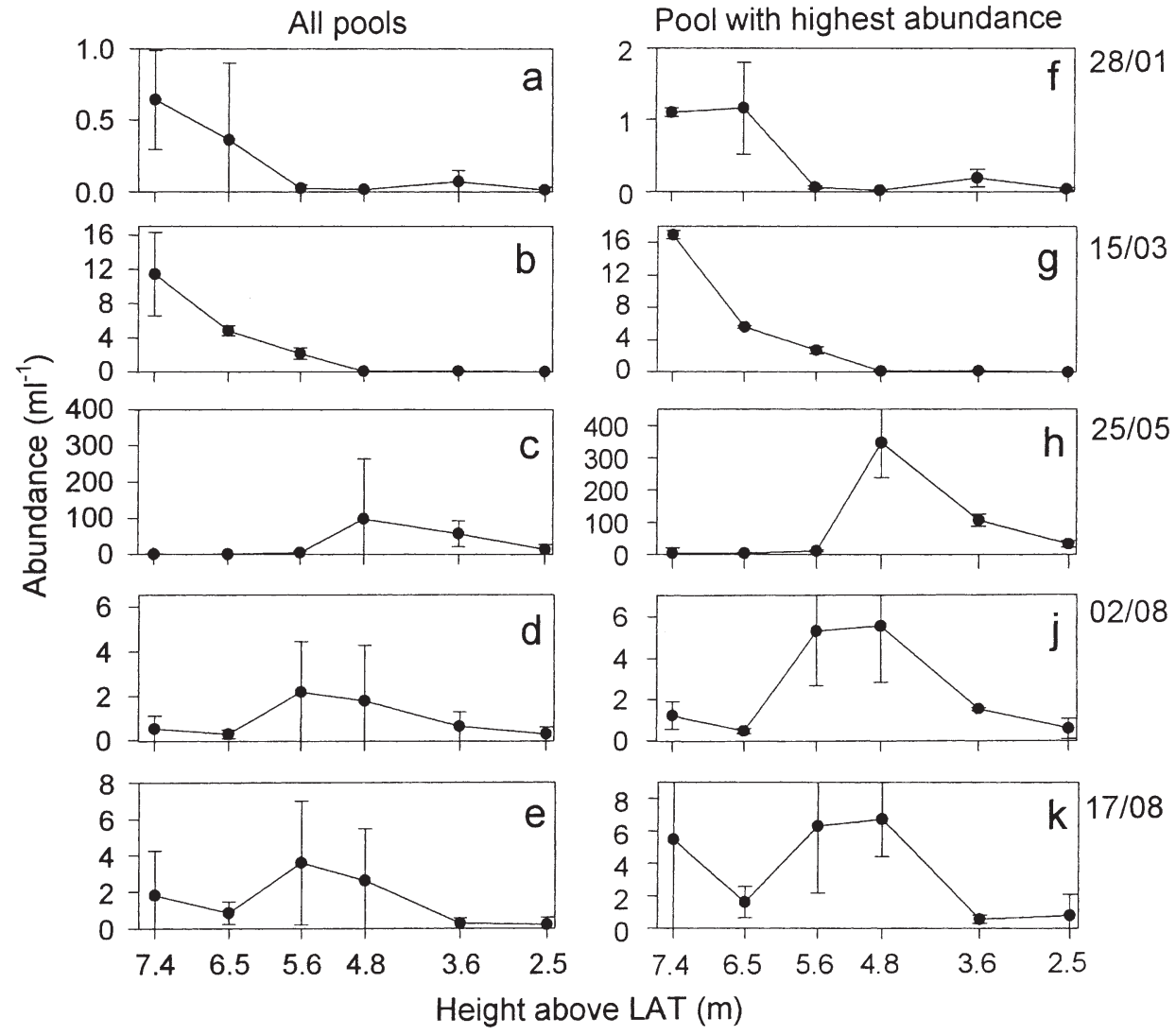


different shore heights. When only the pool with the highest ciliate abundance at each shore height was considered (see 'Materials and methods'), significant differences between heights were revealed, except for data collected on 17 August 1998 (Fig. 8f to j). Multiple comparisons suggested that ciliates were rare at lower pools at all times of the year. In the winter ciliates were more abundant in upper-shore pools, and in the spring and summer ciliates were more abundant in mid-shore pools. Note that these trends have been obtained by using only the pool with the highest abundance of ciliates from each height, and they are based on the assumption that these pools represent a potential maximum abundance at that height.

\section{Encystment-excystment study}

The data indicate the presence of 2 temporally isolated populations, occurring in alternating low tides, both displaying a 6:19 h encystment-excystment cycle (Fig. 9). From trends illustrated in Fig. 9 and similar experiments (data not shown) the following general trend was observed for both populations: (1) at low tide, immediately after sampling, there were no cysts in the wells; (2) the number of cysts increased for $\sim 3 \mathrm{~h}$ after low tide until a plateau was reached; (3) 2 high tides and 1 low tide later $(\sim 19 \mathrm{~h})$ the number of cysts decreased, as ciliates excysted; and (4) encystment occurred 4 to $6 \mathrm{~h}$ after this, with the number of cysts exceeding the number prior to excystment (i.e. population growth occurred).

A second remarkable feature of these data (Fig. 9, and other experiments not shown) is that only $50 \%$ of the cysts, formed during the first $19 \mathrm{~h}$, excysted; the other $\sim 50 \%$ remained encysted. These experiments were not designed to determine the extended length of time that ciliates remained encysted. However, from these data it appears that the entire population does not all follow a 6:19 h cycle; some ciliates may skip 1 or several low tides before excysting.

Microscopic observation revealed that a small proportion of the nighttime population (a-population, Fig. 9) did not follow the 6:19 $\mathrm{h}$ excysted-encysted cycle. Instead, some ciliates (2 to $5 \%$ ) excysted after only $6 \mathrm{~h}$ of being encysted (arrows, Fig. 9), coinciding with excystment of the daytime population (b-population). It was not possible to determine when these ciliates next encysted, but we speculate that they follow the timing of their 'new population' effectively swapping between populations.

\section{Growth rate}

Specific growth rate was estimated from laboratory studies (e.g. Fig. 9, unpubl. data), using the change in the number of cysts just prior to and just after a freeswimming period (e.g. between 20 and $33 \mathrm{~h}$, a-population, Fig. 9). Specific growth $(\mu)$ was calculated as $\mu=\ln \left(\mathrm{N}_{t} / \mathrm{N}_{0}\right) / t$, where $\mathrm{N}_{t}$ and $\mathrm{N}_{0}$ are final and initial numbers, and $t$ is time in days. Specific growth rate ranged between 0.2 to $0.6 \mathrm{~d}^{-1}$ (Fig. 9) and 0.46 to $0.56 \mathrm{~d}^{-1}$ (unpubl.).

\section{DISCUSSION}

The intertidal habitat is a high-disturbance environment, characterised by cyclical fluctuations in abiotic factors on shortand long-term scales. This zone lends itself to population and community studies and has been extensively used to develop and test general ecological models (Raffaelli \& Hawkins 1996). Furthermore, tide pools may act as a model system to assess metapopulation dynamics, as individual pools may harbour populations that are part of a larger shore-wide metapopulation. As indicated in the introduction, the combination of tide pools and protozoa is well suited to use for field-based models of population
Fig. 9. Strombidium oculatum. Laboratory data indicating 2 populations in a single pool. Lower panel: the number of $S$. oculatum cysts in wells of tissue cultures plate over $\sim 40 \mathrm{~h}(\mathrm{n}=3$ wells, error bars $=1 \mathrm{SE})$; ciliates were collected from 2 consecutive low tides: a-population (open circles) collected at 18:20 $\mathrm{h}$ and b-population (filled circles) collected at 06:40 $\mathrm{h}$. Arrows refer to points where several encysted ciliates in a-population excysted synchronously with the b-population excystment. Upper panel: tidal height at the time of laboratory-based data collection; dark bars on top of the panel refer to nighttime, and light bars refer to daytime 
Fig. 10. Conceptual model of the cycles of Strombidium oculatum. (a) Timing of cycles on a log scale; (b) 6 cycles exhibited by $S$. oculatum (note that the evolutionary scale was not discussed in this work); (c) abiotic forces influencing the cycles; (d) behaviours exhibited at the various scales; (e) predictability of the abiotic forces influencing the behavioural cycles; (f) 'functional unit' that is most acted on by the factors indicated in $d$. This schematic diagram is by no means all encompassing, but it suggests trends: as the duration of cyclical scales increases, the predictability of the influencing factor decreases; concomitantly, as predictability decreases, cycles tend to move from being endogenously to exogenously driven; and, finally, this change from endogenous to exogenous cycle is reflected in a change in the functional unit from the individual through to the metapopulation

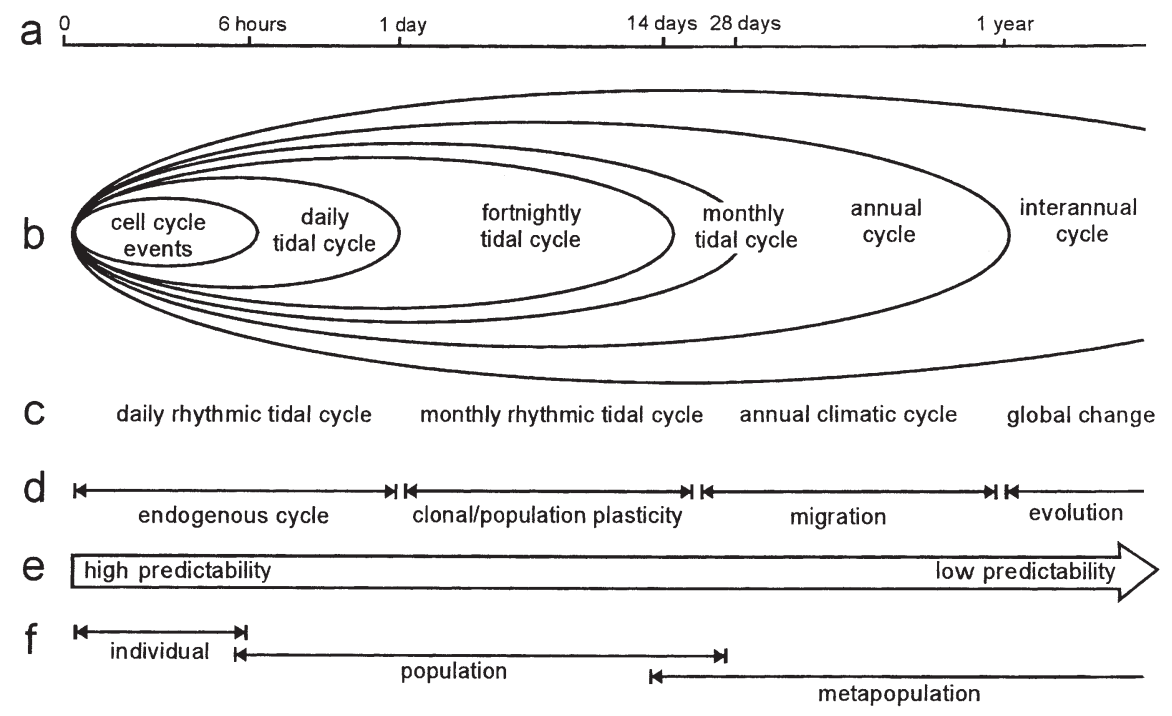

dynamics. However, prior to developing complex population-metapopulation studies, there is a need to assess the basic population dynamics of tide-pool protozoa (Johnson 2000). In this work we have provided detailed information on how an abundant tide-pool protozoan survives.

In addition to the tidal cycle, light, temperature, salinity and wave action vary, on the rocky shore, on scales ranging from hours to years. These factors inevitably influence organisms finding themselves in tide pools. Consequently, behavioural and morphological mechanisms for remaining in pools would undoubtedly have evolved. Behaviours phased to the tidal cycle are often found for organisms inhabiting the intertidal zone, including rhythms phased to high- and low-tide periods, modal and bimodal tidal rhythms, and circalunar rhythms (Palmer 1995). Despite the complexity of the tidal cycle and its susceptibility to climatic modification, there are many endogenous, rather than exogenous, rhythms phased to tidal cycles (Palmer 1995). However, there are also exogenously induced cycles, as internal clocks are unable to cope with less regulated factors.

In the following discussion we examine the dynamics of Strombidium oculatum populations and how the ciliate remains phased to the low-tide period despite fluctuations in the tidal cycle and other environmental pressures. We suggest that populations cycle spatially and temporally in response to environmental fluctuations, occurring on a range of scales from hours to years. We then explore how the highly plastic endogenous circatidal rhythm coupled with a variety of exogenously induced behaviours enables ciliate populations to survive this high-stress environment (Fig. 10).

\section{The circatidal cycle}

Strombidium oculatum, found on British and French shores, has adapted to survive by developing an endogenous encystment-excystment cycle. The ciliate avoids displacement during high tides and exploits the low-tide tide-pool habitat (Fauré-Fremiet 1948a, Jonsson 1994 , this study). For $\sim 6$ h, at low tide, S. oculatum is free-swimming in pools, and $\sim 20$ to $60 \mathrm{~min}$ before flushing of the pools it encysts on a variety of substrates (Jonsson 1994). Encystment lasts for 19 h: 2 high tides and 1 intervening low tide. Excystment then occurs the next day 30 to $40 \mathrm{~min}$ after the pools are isolated. This endogenous cycle persists for several days when ciliates are removed to the laboratory (Fauré-Fremiet 1948a, Jonsson 1994, Montagnes \& Wilson 1998, this study) and is also evident in field observations (Figs. $3 \& 4$ ). However, we have also indicated that a large proportion of the cells remain encysted for more than $19 \mathrm{~h}$ (Fig. 9, unpubl. data). How long these cells remain encysted is unknown, but this extension of the encysted stage has implications for the survival of populations (see below).

While enabling the ciliate to remain within pools, this endogenous mechanism confines the free-swimming stage of the cell cycle to a brief $\sim 6 \mathrm{~h}$ period during low tide. Since division only occurs when the ciliate is free-swimming, population growth occurs only during low tides. During low tides, populations experience losses; ciliate numbers decrease (Figs. 3 $\& 4$ ), probably by zooplankton predation (see below). Thus, for a population to remain stable, sufficient growth must occur during the relatively short low-tide period. How then do ciliates optimise this brief $6 \mathrm{~h}$ window? 


\section{The low-tide cell cycle}

Environmental pressures might select for the timing of cell division at a defined point during the free-swimming period. For example, ciliates might excyst, after $19 \mathrm{~h}$ undernourishment and require a period of feeding and somatic growth prior to cell division-analogous situations may occur for organisms that undergo diapause or hibernation. Alternatively, ciliates and other organisms may potentially consume all of the prey (nanoflagellates) in a pool during low tide (Jonsson 1994); in this case, food would become limiting, and dividing soon after excystment would provide a competitive advantage by increasing numbers and allowing ciliates to rapidly exploit the resource. Again, parallels can be drawn with $r$-selected metazoa (Begon et al. 1986) and with parasitic protozoa that divide rapidly after excysting within a host (Feely et al. 1990).

Strombidium oculatum exhibits the latter, exploitative strategy, and we have indicated a mechanism by which rapid population growth can occur soon after ciliates excyst: ciliates excyst having undergone DNA synthesis in the macronucleus during the previous free-swimming period (Fig. 3; Lowe \& Montagnes 2001). Thus, for the entire encystment period $(\sim 19 \mathrm{~h})$ the macronuclear DNA is replicated. Although we have not observed nuclei in encysted cells, ciliates do not appear to divide in cysts (Jonsson 1994, unpubl. observations). In this study, because division and DNA replication were observed during the free-swimming period, we assume that the $\mathrm{G}_{2}$ pause, the period between macronuclear DNA synthesis and cell division, is extended throughout encystment. Thus, when ciliates excyst at the start of the next low tide, they are immediately able to divide (Fig. 3).

The process of extending the $\mathrm{G}_{2}$ pause differs from that of many other ciliates, as ciliates often undergo macronuclear DNA replication and then divide relatively soon after, i.e. the $\mathrm{G}_{2}$ pause occupies a relatively short portion of the cell cycle (Raikov 1996). In contrast, the $\mathrm{G}_{2}$ pause seems to occupy $\sim 70 \%$ of the cell cycle in Strombidium oculatum. Similar extension of $\mathrm{G}_{2}$ is seen in some parasites that rapidly exploit their host after excystment (Feely et al. 1990). We suggest that $S$. oculatum has a modified cell cycle that allows it to synchronise the division and excystment cycles to exploit the predictably available food source in pools; by dividing soon after the start of low tide, the ciliate exploits food resources and out-competes other grazers.

\section{The monthly and fortnightly tidal cycles}

As indicated above, Strombidium oculatum populations maintain net growth by cells exhibiting an endogenous encystment-excystment cycle and by the specific timing of the cell cycle. However, the duration of the low-tide period changes on a spring-neap cycle, and over a month pools may vary in their time of isolation by minutes to hours. Thus, ciliates must be adapted to cope with cycles of a longer duration than those described above.

Monthly changes in the tidal cycle influence the survival of ciliate populations if their endogenous clocks inaccurately predict when pools are covered and uncovered. If ciliates are still free-swimming when the pool is covered, they will be flushed from the pool; such events were observed in several of our studies (Figs. $3 \& 4 a, b)$. Furthermore, if ciliates excyst late in the cycle, they may be at a disadvantage if their food resource is consumed by competitors.

Although the spring-neap tidal oscillation is predictable, it is complex; thus, the existence of an endogenous rhythm that matches this cycle is unlikely. Rather than relying on a complex endogenous cycle, monthly phasing in Strombidium oculatum populations is maintained by variation in the timing of the encystment cycle within a population (Jonsson 1994). Jonsson (1994) demonstrated that the timing of the endogenous cycle tends to be inherited: daughter cells exhibit a similar timing to that of their parent. Thus, those cells that survive the change in timing due to the monthly tidal cycle establish a population with a different encystment-excystment cycle.

It appears, however, that there is still some impact of the spring-neap cycle on population size. Johnson (2000) indicated that the abundance of Strombidium oculatum populations oscillated in phase with the spring-neap cycle; he suggested that increased tidal exposure during neap tides resulted in increased stress and, therefore, mortality of ciliate populations. Equally, however, mortality associated with tidal flushing could account for this oscillation in ciliate abundance; modelled populations show increasing mortality due to tidal flushing on the transition from spring to neap tides and decreased mortality on the transition from neaps to springs (Jonsson 1994). Thus, although the ciliate is adapted to the spring-neap cycle, there is the potential for the reduction and possible extinction of local populations, especially on the upper and lower shores, where exposure and flushing would have the most extreme affect.

In addition to the spring-neap cycle, a second cycle occurs on a monthly scale. The tidal cycle exceeds the solar day by $50 \mathrm{~min}^{-1}$; consequently, twice during a lunar month, low tides oscillate between day and night. As a result, within a single tide pool, freeswimming ciliate populations sequentially experience a nocturnal and diurnal low-tide environment. This transition is a further environmental pressure to which populations are exposed. 
We have supported the prediction of Jonsson (1994) that 2 temporally isolated populations occur within a single pool. Both display the characteristic $6: 19 \mathrm{~h}$ encystment cycle, but each is phased to alternating low tides (Figs. 4 to 6). Populations occurring during the day are larger (Figs. 4a \& 5; Jonsson 1994), and the relative abundance of the 2 populations changes as low tides switch between night and day (Fig. 5). We speculate that larger daytime populations are maintained primarily in response to predictable environmental factors: light and temperature. Temperature is one of the main factors governing the growth rates of ectotherms. Strombidium spp. grow slower in the cold (Montagnes 1996) and, in general, daytime temperatures were higher than those in the night (e.g. $\Delta=7^{\circ} \mathrm{C}$, Fig. 4); thus, a greater proportion of the daytime population may divide, resulting in the observed increase in population size. Light may also influence the population dynamics within a pool. The importance of light on the rhythms and growth of protists is well documented (e.g. Palmer \& Round 1965a, Eaton \& Simpson 1979). Specifically, Strombidium oculatum uses a phototactic response, orienting itself in pools to facilitate encystment (Fauré-Fremiet 1948a, Jonsson 1994, Montagnes et al. 2002). Furthermore, S. oculatum is mixotrophic (Jonsson 1994, Montagnes et al. 2002), sequestering plastids that it uses for photosynthesis during both encysted and free-swimming phases. Therefore, due to both increased temperature and light levels during the day, daytime populations might have a selective advantage over those occurring at night.

An alternative, but not mutually exclusive, hypothesis is that top-down predator control reduces population size at night. Tide-pool copepods were more abundant in our night samples (unpubl.). Copepods are ciliate predators (Stoecker \& Capuzzo 1990) and, specifically, tide-pool harpacticoid copepods consume Strombidium oculatum (unpubl.). As zooplankton likely exhibit diurnal vertical migrations in pools, remaining near the bottom during the day (see Ganning 1967), predation pressure would presumably be greater at night. An analogous situation occurs in freshwaters, where zooplankton migrate horizontally, spending the day among littoral macrophytes to avoid fish predation; they then migrate out to feed on plankton at night (Timms \& Moss 1984, Lauridsen \& Lodge 1996).

Thus, there appear to be predictable bottom-up (light and temperature) and top-down (zooplankton predation) pressures on Strombidium oculatum to have its $6 \mathrm{~h}$ free-swimming stage coincide with the daytime low tide. These pressures result in larger daytime populations. However, as previously noted, the $\sim 25 \mathrm{~h}$ tidal cycle forces a daytime population to become a nighttime population each lunar month. If there are benefits to remaining in the daytime low tide, then ciliates might selectively transfer between the temporally isolated populations. Such a hemilunar phenomenon occurs in the benthic, psammobiotic diatom Hantzschia virgata (Palmer \& Round 1965b). To photosynthesise, this diatom migrates to the surface of sandy beaches during low tide and then migrates into the sediment to avoid flushing by the high tide. The diatom migrates to the surface only during daytime low tides and is able to re-phase when low tide occurs at dusk. Thus, whole populations are able to swap between low tides so that they always occur during the day.

Our data indicate that a hemilunar transfer of individuals between tides might also occur for Strombidium oculatum, with an apparent preference towards the daytime low tide (arrows, Fig. 9). As these data are from a single observation of this behaviour, our findings are speculative, and we are left with the question of why only a small portion of the population excysted out of phase. For intertidal benthic diatoms that display circatidal migrations, there are no nocturnal populations (Palmer 1995). As diatoms migrate to the surface to photosynthesise, there is no need to migrate at night. In $S$. oculatum, however, there are nocturnal populations, suggesting that while it might be advantageous to occur during the day, the nighttime low tide is an exploitable environment, and there is not a strong selection pressure to remain only in the daytime low tide. Furthermore, there may be constraints to maintaining a $6: 6 \mathrm{~h}$ cycle. For instance, producing cysts every $6 \mathrm{~h}$ or maintaining population growth under varying conditions might be too energetically costly for the ciliate (Jonsson 1994).

We also noted a second potential means of transfer between populations: during laboratory studies, appreciable proportions of ciliates remained within cysts during low tide, when most of the population was freeswimming (Fig. 9). The length of this encystment is unknown. If cells remain encysted for only 1 or 2 cycles, this may be a method of ensuring that shortterm, episodic disasters (e.g. waves or rain) do not cause extinctions. In contrast, such encystment may provide a mechanism for transfer between tides. Alternatively, long-term (e.g. months) encystment may offer a means to survive unfavourable conditions e.g. winter periods, a common use of the encystment strategy for protozoa and metazoa (Corliss \& Esser 1974, Kim \& Taniguchi 1997, Müller \& Wunsch 1999). Thus, there are further potential adaptations of the encystment behaviour in $S$. oculatum that may modify longer-term survival. 


\section{The seasonal and spatial-variation cycle}

Short-term temporal changes in ciliate populations occur due to fluctuations in the tidal cycle. In addition, there are longer-term fluctuations that occur on a seasonal scale. These long-term environmental changes influence both the population abundance at a single site and the vertical distribution of the ciliate on the shore.

Long-term observations of ciliate abundance in a mid-shore pool show that abundance is greatest between May and July, and declines to virtually no ciliates in the autumn and winter (Fig. 6). There was no clear relation between the increase in ciliate abundance and salinity over the annual cycle (data not shown). In contrast, there was a coincidence between the onset of the spring-time population increase and the increase in light and temperature levels. As Strombidium oculatum is mixotrophic and thus depends on light for photosynthesis and for the growth of its autotrophic prey (Jonsson 1994), it might be expected that light levels influence population dynamics. Furthermore, as indicated above, increased temperature during the spring would likely raise population growth rates (Montagnes 1996). Finally, another strombidiid, $S$. conicum, follows a seasonal encystment-excystment cycle: a rise in sediment temperature stimulates excystment (Kim \& Taniguchi 1997). We speculate that $S$. oculatum follows a similar, environmentally induced, long-term excystment pattern. Thus, when light levels rose above $\sim 13 \mathrm{~h}$ of light $\mathrm{d}^{-1}$ or 5 to $6 \mathrm{~mol} \mathrm{~m}^{-2} \mathrm{~d}^{-1}$ and temperature rose above $10^{\circ} \mathrm{C}$, it is not surprising that the abundance of $S$. oculatum rose (Fig. 6). This illustrates an exogenous stimulation for the population dynamics of $S$. oculatum. There was, however, no similar relationship between the decline of the population in the autumn and temperature and light levels. Possibly, the increase of flushing by waves, driven by autumn storms, resulted in the population decline at the end of the summer.

A remarkable point is that the population in the long-term, mid-shore pool decreased or disappeared in the late autumn (Fig. 6). We are left with the question of how populations survive the winter. As indicated above, some strombidiids form overwintering cysts (Kim \& Taniguchi 1997, Müller \& Wunsch 1999). The daily-formed cysts used by Strombidium oculatum resemble these overwintering cysts (Montagnes et al. 2002); thus, we predict that these cysts are used for long-term survival, although we have not observed this behaviour. Another possible means of survival of $S$. oculatum is that remnant populations survive in the upper shore during the winter.

Although the data are not strong (see 'Results'), they suggest that the vertical distribution and abundance of
Strombidium oculatum changes seasonally. During the spring and summer, ciliate abundance appears to be highest and peaks in mid-shore pools (Fig. 8). While ciliate abundance is low at all shore heights during the winter, the highest relative abundance occurs in upper-shore pools. High-shore positions are likely to experience less wave action, and thus these pools might provide a refuge from erratic flushing in winter. Then in the spring, these high-shore pools could be a source for re-seeding the low-shore pools. Consequently, we suggest that the vertical zonation and fluctuations in abundance noted on a seasonal scale are entirely exogenously induced by wave action, light and temperature.

\section{Population structure and survival}

We have indicated that a series of endogenously and exogenously induced cycles influence the population dynamics of Strombidium oculatum (Fig. 10). Individual ciliates survive by following a series of cyclical behaviours, and variation in the timing of cycles between individuals lends robustness to a population. Consequently, populations persist despite unpredictable variation in environmental factors.

Within an individual tide pool, 2 temporally isolated populations occur, and each pool is a discrete habitat patch, of which there are many on a rocky shore. Thus, individual pools harbour populations of a larger rocky-shore metapopulation, and we speculate that there are complex dynamics between pools on a rocky shore. Even in regions of the shore where populations of Strombidium oculatum should thrive, there is often considerable interpool variation (Fig. 8), and by a variety of biotic and abiotic mechanisms, a population within a pool can become extinct or be drastically reduced. Furthermore, transfer may occur between pools, as ciliates may excyst before pools are uncovered or remain excysted after pools are covered (e.g. Fig. 4). Thus, we speculate that although individual pools may loose ciliates, metapopulation stability across a shore is maintained; a similar recolonisation strategy of tide pools by the dinoflagellate Peridinium gregarium has also been inferred (Lombard \& Capon 1971), and similar trends have been suggested for other tide-pool organisms (Johnson 2000).

A population may decline by a variety of processes. Cyclical behaviours are susceptible to erratic fluctuations in abiotic cycles, and, as indicated above, these fluctuations are especially pronounced in the intertidal zone. Such losses range from occasional catastrophic displacement of entire populations (Jonsson 1994, this study) to regular displacement of a variable proportion 
(1 to $35 \%$, this study, Jonsson 1994) at the end of lowtide periods, when ciliates fail to encyst in time (e.g. Figs. 3 \& 4). Losses may also occur if ciliates prematurely excyst, before a pool is isolated by the ebbing tide, but we have yet to quantify this parameter. Topdown and bottom-up pressures also may reduce ciliate populations in pools. Our data suggest that losses over the $6 \mathrm{~h}$ low-tide period almost equal population growth; this is based on data indicating a constant decrease in ciliate numbers over much of the freeswimming period (Fig. 3), while encystment occurs primarily near the end of the free-swimming period (Fig. 9, other data not shown). At times, grazers theoretically could remove ciliate populations. Ciliates could also starve if the abundance of nanoflagellates, the putative prey for Strombidium oculatum, is sufficiently low; other reports indicate that strombidiids die within days when they are starved (e.g. Montagnes 1996). However, for 2 reasons, we speculate that starvation is unlikely for $S$. oculatum: the ciliate is mixotrophic, which may be an adaptation to living in food-depleted environments (Stoecker 1998), and tide pools tend to be nutrient-replete environments (Jonsson 1994), where nanoplankton should thrive. A final top-down control of ciliates might be by benthic grazers consuming cysts. Limpets and other gastropods are common inhabitants of tide pools and may reduce populations when ciliates are encysted; we have yet to quantify this parameter.

How then do depleted populations recover? Ciliates can potentially divide once per day (Jonsson 1994, this study). Thus, populations would easily be re-established, if growth were unlimited. Such unlimited growth would predictably occur at low ciliate densities, where grazing pressures and competition for food are reduced. In contrast, it is unlikely that immigration from other pools is a significant component of population growth: simple calculations (using data presented above) indicate that the number of cells flushed into new pools would be orders of magnitude lower than the potential increase in numbers of the resident population.

However, the role of immigration is potentially important to maintain gene flow between populations and for population dynamics. While mortality of Strombidium oculatum flushed from pools may account for a large number of displaced individuals, herein lies a potential mechanism for dispersal of ciliates between tide pools. Such dispersal may provide a mechanism by which pools that lack ciliates are re-seeded. Clearly, such transfers have occurred in the past, as the ciliate is found in France and in the British Isles (FauréFremiet 1948a, Jonsson 1994, Montagnes et al. 2002), and there are reports of its existence in Atlantic tide pools on the northern shore of Spain (O. Santamaria
Estepar pers. comm.) and possibly on the east coast of the United States (G. McManus pers. comm.). This wide distribution raises questions: e.g. if $S$. oculatum encysts after $\sim 6 \mathrm{~h}$, how can it be displaced to distant shores (e.g. the Isle of Man)? To our knowledge, S. oculatum has never been observed in the plankton. Also, how does the ciliate survive the winter? Our data suggest that populations virtually disappear during the late autumn and appear again only in mid-spring (Fig. 6). Are there resting cysts that allow the ciliate to survive for long periods (e.g. Corliss \& Esser 1974, Kim \& Taniguchi 1997, Müller \& Wunsch 1999), and could these be a mechanism for dispersal?

Furthermore, we have only once observed conjugation in Strombidium oculatum (unpubl.); possibly sex occurs seasonally. Pools may contain clonal populations; if this is so, there is the potential for clonal decline within a pool over $\sim 100$ to 200 generations (Bell 1988, Montagnes et al. 1996). Assuming that ciliates divide approximately once per day (Jonsson 1994, this study), this would require sex at least once per growth season (i.e. once per year). Sex in ciliates may be stimulated by starvation and temperature changes (Nanny 1980, Dini \& Nyberg 1993); possibly at the end of the growth season, when light levels reduce food availability (see above) and seasonal temperature drops (Fig. 6), ciliates are stimulated to conjugate. Potential transfer between pools (i.e. populations) would thus ensure genetic diversity within pools and reduce the likelihood of inbreeding within a clonal population. Determining the clonal variation between populations on the rocky shore is beyond this work. However, we are now beginning a study that will employ molecular techniques to evaluate clonal diversity of protists within and between shores and pools.

In this study we have parameterised a number of cyclical behaviours that allow populations and metapopulations of Strombidium oculatum to survive on the rocky shore (Fig. 10). We have also hypothesised a number of behaviours that may have evolved to further benefit the ciliate. Thus, we have provided the basis to develop the simple models and speculations presented by Fauré-Fremiet (1948a,b), Jonsson (1994) and Johnson (2000). Clearly protozoa in tide pools on the rocky shore provide an ideal environment to study metapopulation dynamics. We suggest the next step should be to develop such models.

Acknowledgements. We thank Port Erin Marine Laboratory and the University of Liverpool for use of their facilities. Thanks are also given to Laurent Froget, David Goodwin, Iain Jackson, Suzanne Kay, Jason Mallard, Nicola Palmer, Alex Poulton, Oscar Santamaria Estepar and Nicholas Wady, who assisted in sampling. We give specific thanks to Joanna 
Jones and Jason Mallard, who, respectively, provided and processed the Port Erin light data. Kevin Kennington provided the inspiration to concentrate ciliates with a coffee maker. We also thank 2 anonymous reviewers for their constructive comments. This study was partially funded by grants from the British Ecological Society (SEPG No. 1416, 1302, 1558), the Royal Society (equipment grant), Systematics Association (for publication costs) and Manx Airlines (2 Project 2000 grants).

\section{LITERATURE CITED}

Begon M, Harper JL, Townsend CR (1986) Ecology, individuals, populations and communities. Blackwell Scientific Publications, Oxford

Bell G (1988) Sex and death in protozoa, the history of an obsession. Cambridge University Press, Cambridge

Cloudsley-Thompson JL (1961) Rhythmic activity in animal physiology and behaviour. Academic Press, London

Corliss JO, Esser SC (1974) Comments on the role of the cyst in the life cycle and the survival of free living protozoa. Trans Am Microsc Soc 93:578-593

Dini F, Nyberg D (1993) Sex in ciliates. In: Jones JG (ed) Advances in microbial ecology. Plenum Press, New York, p 85-153

Eaton JW, Simpson P (1979) Vertical migrations of the intertidal dinoflagellate Amphidinium herdmaniae Kofoid and Swezy. In: Naylor E, Hartnoll R (eds) Cyclic phenomena in marine plants and animals. Pergamon Press, Oxford, p 339-346

Fauré-Fremiet E (1948a) Le rythme de marée du Strombidium oculatum Gruber. Bull Biol France Belg 82:3-23

Faure-Fremiet E (1948b) The ecology of some infusorian communities of intertidal pools. J Anim Ecol 17:127-130

Fauré-Fremiet E (1953) La bipartition énantiotrope chez les ciliés oligotriches. Arch Anat Micro Morphol Exp 42: 209-225

Feely DE, Holberton DV, Erlandsen SL (1990) The biology of Giardia. In: Meyer EA (ed) Human parasitic diseases, Vol 3. Giardiasis. Elsevier, Oxford, p 11-49

Ganning B (1967) Laboratory experiments in the ecological work on tide-pool animals with special notes on the ostracod Hetercypris salinus. Helgol Wissenschaftliche Meeresunters 15:27-39

Gause GF (1934) The struggle for existence. Williams and Wilkins, Baltimore, MD

Hanski IA, Gilpin ME (1997) Metapopulation biology, ecology, genetics, and evolution. Academic Press, London

Hasle GR (1978) The inverted-microscope method. In: Sournia A (ed) Phytoplankton manual. UNESCO, Paris, p 88-96

Holyoak M (2000) Effects of nutrition enrichment on predatorprey metapopulation dynamics. J Anim Ecol 69:985-997

Johnson MP (2000) Physical control of plankton population abundance and dynamics in intertidal rock pools. Hydrobiologia 440:145-152

Jonsson PR (1994) Tidal rhythm of cyst formation in the tidepool ciliate Strombidium oculatum Gruber (Ciliophora, Oligotrichida): a description of the functional biology and an analysis of the tidal synchronization of encystment. J Exp Mar Biol Ecol 175:77-103

Kim YO, Taniguchi A (1997) Seasonal variation of excystment pattern of the planktonic oligotrich ciliate Strombidium

Editorial responsibility: John Dolan,

Villefranche-sur-Mer, France conicum. Mar Biol 128:207-212

Lauridsen TL, Lodge DM (1996) Avoidance by Daphnia magna of fish and macrophytes: chemical cues and predatormediated use of macrophyte habitat. Limnol Oceanogr 41: 794-798

Lombard EH, Capon B (1971) Observations on the tidepool ecology and behavior of Peridinium gregarium. J Phycol 7:188-194

Lowe CD, Montagnes DJS (2001) Population growth strategies of a rock pool ciliate, Br Ecol Soc Bull 32:24-25

Montagnes DJS (1996) Growth responses of planktonic ciliates in the genera Strobilidium and Strombidium. Mar Ecol Prog Ser 130:241-254

Montagnes DJS, Wilson D (1998) Population dynamics of a rock-pool ciliate, a model system. Br Ecol Soc Bull 29:25

Montagnes DJS, Berger JD, Taylor FJR (1996) Growth rate of the marine planktonic ciliate Strombidinopsis cheshiri Snyder and Ohman as a function of food concentration and interclonal variability. J Exp Mar Biol Ecol 206: 121-132

Montagnes DJS, Lowe CD, Poulton A, Jonsson PR (2002) Redescription of Strombidium oculatum Gruber 1884 (Ciliophora, Oligotrichia). J Eukaryot Microbiol 49 (in press)

Müller H, Wunsch C (1999) Seasonal dynamics of cyst formation of pelagic strombidiid ciliates in deep prealpine lake. Aquat Microb Ecol 17:37-47

Nanny DL (1980) Experimental ciliophorology: an introduction to genetic and developmental analysis in ciliates. John Wiley and Sons, New York

Palmer JD (1995) The biological rhythms and clocks of intertidal animals. Oxford University Press, Oxford

Palmer JD, Round FE (1965a) Persistent, vertical-migration rhythm in benthic microflora I. The effect of light and temperature on the rhythmic behaviour of Euglena obtusa. J Mar Biol Assoc UK 45:567-582

Palmer JD, Round FE (1965b) Persistent vertical migration rhythms in benthic microflora. VI. The tidal and diurnal nature of the rhythm in the diatom Hantzschia virgata. J Mar Biol Assoc UK 45:44-55

Raffaelli D, Hawkins S (1996) Intertidal ecology. Chapman and Hall, London

Raikov IB (1996) Nuclei of ciliates. In: Hausmann K, Bradbury PC (eds) Ciliates, cells as organisms. Gustav Fischer, Stuttgart, p 221-242

Scherren H (1900) Ponds and rockpool with hints on collecting for and the management of the micro-aquarium. The Religious Tract Soc, London

Sherr EB, Caron DA, Sherr BF (1993) Staining of heterotrophic protists for visualization via epiflourescence microscopy. In: Kemp PF, Sherr BF, Sherr EB, Cole JJ (eds) Handbook of methods in aquatic microbial ecology. Lewis Publishers, Boca Raton, p 213-228

Stoecker DK (1998) Conceptual models of mixotrophy in planktonic protists and some ecological and evolutionary implications. Eur J Protistol 34:281-290

Stoecker DK, Capuzzo JM (1990) Predation on protozoa: its importance to zooplankton. J Plankton Res 12:891-908

Throndsen J (1978) Preservation and storage. In: Sournia A (ed) Phytoplankton manual. UNESCO, Paris, p 69-74

Timms RM, Moss B (1984) Prevention of growth of potentially dense phytoplankton populations by zooplankton grazing, in the presence of zooplanktivorous fish, in a shallow wetland ecosystem. Limnol Oceanogr 29:472-486

Submitted: December 10, 2001; Accepted: February 14, 2002 Proofs received from author(s): April 22, 2002 